\author{
Molnár Mária \\ Pécsi Árpád Fejedelem Gimnázium és Általános Iskola \\ Pécsi Tudományegyetem \\ molnar0430@gmail.com
}

\title{
„NE BESZÉLJÜNK SUKSÜK, SZUKSZÜK NYELVEN...!” TILTÁS ÉS KÖVETKEZETLENSÉG 21. SZÁZADI ANYANYELVI NEVELÉSÜNK OKTATÁSI GYAKORLATÁBAN
}

\section{Bevezetés}

A címben szereplő idézet Lerchné dr. Egri Zsuzsanna 6. évfolyamra készült tankönyvéből való (Lerchné 2016: 101). Ezzel kívántam reprezentálni azokat a tiltásokat, amelyek magyar nyelvi tankönyveinkben napjainkban elöfordulnak. Olyan nyelv- és normaszemléletbeli problémákat, következetlenségeket kívánok bemutatni tankönyvi szövegrészletek és a gyakorlati tudásanyagot reprezentáló feladatok alapján, amelyek megakadályozzák a valós nyelvhasználat tanítását az oktatás gyakorlatában. Alapvető társadalmi szükséglet ugyanis, hogy anyanyelvoktatásunk megfeleljen korszakunk, a 21. század kommunikációs és nyelvhasználatbeli kihívásainak: a magán- és közéletben, valamint a munka világában elboldoguló, érdekeit árnyaltan érvényesíteni és másokkal jó kapcsolatot kialakítani képes, a tanulás világába bármikor visszakapcsolódni tudó, a folyamatosan és gyorsan változó feladatokhoz alkalmazkodni képes egyén nyelvi-kommunikációs nevelésének.

Mégsem kizárólag tankönyvkritikát kívánok nyújtani, hanem konkrét javaslatokat egyes feladatok, illetve szövegrészletek módosításához. Továbbá egy nagy mintán végezett, magyar nyelvi tankönyveink normaszemléletére vonatkozó kutatómunkám eredményei alapján általános javaslatokat teszek anyanyelvi nevelésünk nyelv- és normaszemléletének megváltoztatására.

\section{Tiltások és következetlenségek sora magyar nyelvi tankönyveinkben}

2.1. A tanulmány címében megjelenített tankönyvi szövegrész a következő:

(1) Ne beszéljünk suksük, szukszük nyelven, vagyis ne cseréljük föl a -t végü igék kijelentő és felszólító módú alakjait az igényes nyelvhasználatban! (Lerchné 2016: 101) 
Hogy hat ez tiltás a tanulók nyelvi attitüdjére?

A tankönyvi szövegrészlet perskriptív személetet közvetít. Ezáltal azt tanulják meg a diákok, hogy pusztán a helyesség-helytelenség tengelyén értékelhetők a nyelvi megnyilatkozások. És mindezt az igényes nyelvhasználatra hivatkozással teszi a tankönyv, amely egyértelműen hibának tekinthető, hiszen összemossa a nyelvváltozat és a stílus fogalmát. Minden nyelvi variánst lehet ugyanis igényesen és igénytelenül is használni. Az igényesség stilisztikai fogalom.

Egy további probléma ezzel az előíró megjegyzéssel, hogy ellentmond a valós nyelvi praxisnak, hiszen a gyerekek igenis találkoznak környezetükben a suksüköléssel (ahogy például a nákolással is). Ezek a nyelvi formák beletartoznak egyes nyelvjárások normájába is. Továbbá ez nézet az igényes nyelvhasználat jegyében és a tiltás következtében a nyelvi diszkriminatív viselkedés kialakulásához vezet: a diákok szituációtól függetlenül megbélyegzik majd azokat a nyelvhasználókat, akik ilyen nyelvi formákkal élnek. Amennyiben saját nyelvváltozatuk normájának is részét képezik ezek a formák, elbizonytalanodhatnak saját és beszélőközösségük nyelvhasználatát illetően is.

2.2. A fenti tankönyvi szövegrészhez tartozó munkafüzetbeli feladatban már árnyaltabban fogalmaz a szerzö:

(2) 11. a) Javítsd ki a mondatoknak azokat a hibáit, amelyek sértik a köznyelvi normát! Mire megjönnek Tónikáék, kitakarícssuk az egész lakást [...]

b) És most hol a hiba? Írd le helyesen a szöveget!

Szivesen vendégül látnák az ünnepség alkalmából két gyereket [...]

(Lerchné 2017: 75)

Megtudjuk, hogy a köznyelvi normát sértő alakokat kell kijavítani (más kérdés, hogy egy hatodikos tanuló érti-e a köznyelvi norma terminust), amelyek azonban hibának minősülnek. A tankönyvben még igényes nyelvhasználatról van szó, de itt egyértelmű, hogy a köznyelvi normától való eltérés minősül hibának. Ebből nyilvánvaló, hogy a köznyelvi norma jelenti az igényes nyelvhasználatot.

Problematikusnak találom emellett azt is, hogy nincs különbségtétel a beszélt és az írott nyelvi változat között, ahogy a kontextus, illetve a szituáció megjelölése is hiányzik a feladatból.

2.2.1. Javaslom, hogy az ilyen jellegủ gyakorlatok helyett olyan feladatokat adjunk a diákoknak az anyanyelvi órán, amelyekben a véleményüket kérjük arra vonatkozólag, hogy egy megnyilatkozás helyénvaló-e egy általunk megadott szituációban. Hiszen a tanuló már az iskolába kerülve birtokosa több normának, így képes arra, hogy különbséget tegyen közöttük. Az iskolai anyanyelvi nevelés feladata az lenne, hogy a köztük lévő választást tudatossá tegye. 
Az általam javasolt feladat (szintén hatodikosokra szabva): Helyénvaló-e az adott szituációban a megnyilatkozás? Ha nem, mi okozza a problémát? Te hogyan mondanád másképpen? Például:

- Irodalomórai feleletedben: „Arany János a nagykörösi gimnáziumba tanitott.”

- Nyelvjárást beszélő nagyanyádnak mondod: „Mink holnap a papával lefessük a keritést.”

- Osztálytársadnak mondod a szünetben: „Ne parázz már ennyire, bátyja, egy társadalmi, állampolgári és gazdasági ismeretekböl irandó irásbeli számonkéréstöl!"

- Egy üzletben egy nálad jóval idősebb eladótól kérdezed: „Nyanya, mennyibe fáj ez a csoki?”

2.3. Egy következő tankönyvi példa - szintén egy általános iskolai magyar nyelvi tankönyvből való:

(3) Lehet, hogy előfordult már veled, hogy azt mondtad: a hét kerületben lakom, vagy hat cés vagyok. Pedig helyesen a 7., azaz a hetedik kerületben, és 6. c osztály. Vigyázz, hogy ezeket a kifejezéseket helyesen használd! (BaloghnéBaranyai 2015: 30)

Mi szerint helyesen?

Az első példa vidéken kevésbé ismert a tanulók számára, a másodikat pedig teljesen természetesnek találom, hiszen használjuk a beszélt nyelvben, és ami még fontosabb, a diáknyelv részének tekinthető. Azaz része a tanuló saját nyelvváltozatá(i)nak. Egy adott szituációban, amelyet nem jelöl meg a tankönyv, teljesen megfelelő lehet.

Így erre a tankönyvi példára is ugyanaz érvényes, mint az előzőre. Amellett, hogy a tankönyv elbizonytalanítja a tanulót saját nyelvhasználatát illetően, a diszkriminatív nyelvi viselkedés kialakulását is elősegíti. Továbbá azt a képzetet kelti, hogy a diák által természetesen használt nyelvi megoldások értékelhetők pusztán a helyesség-helytelenség tengelyén - szituációtól függetlenül annak érdekében, hogy a tanuló mindenkor megfeleljen a tankönyvi szemlélet által egyetlen helyesnek ítélt, minden kommunikációs helyzetben a legcélravezetőbb köznyelvi normának.

2.4. Akaratlanul is a régebbi korok, a 20. századi és a 21. század első évtizedének erős preskriptív szemléletmódja jut eszembe. Ezek a tankönyvek a szubsztenderd variánsok nyelvváltozat mivoltát kérdőjelezték meg. A nyelvi igénytelenséget a gondolkodás szegénységével kapcsolták össze, miközben azok használóját is megbélyegezték nyelvi alapon. Stigmatizálták tehát magukat a tanulókat is!

Álljon itt néhány tankönyvi példa a diáknyelvről, illetve az ifjúsági nyelvről:

(4) A közhelyek, a töltelékszavak, a bugyuta 'diáksóder' nem fejezi ki, amit gondolsz. Ne ragaszkodj hozzá! (Lerchné 2001: 67) 
(5) Az ifúság nyelvében előforduló durva nyelvi formák, trágár szavak nyelvi igénytelenségről, gondolkodásbeli szegénységről árulkodnak. (Antalné-Raátz 2007: 178)

Más nyelvváltozatokról pedig így vallottak:

(6) Igénytelen nyelvváltozatok a szleng és az argó (Antalné-Raátz 2001: 179).

Most, a 21. század második évtizedének végén, a nyelvtudományi szemlélet megváltozásával, már nem tartom helyénvalónak azt a szemléletet, amely a szubsztenderd használatát szituációtól függetlenül tiltja a tanulók számára. Mindenképpen javaslom a normapluralizmus nézetének tananyagba kerülését explicit és implicit formában is. Véleményem szerint a tiltás helyett inkább fel kellene hívni a tanulók figyelmet a különböző stílustípusokra, valamint a nyelv(változatok) identitásjelző funkciójára. Természetesen mindezt az adott korosztálynak megfelelő szinten. Például olyan feladatokat adva a tanulók számára, amelyekben példákat villantunk fel számukra különböző nyelvváltozatokból, illetve a köznyelvi és a szubsztenderd formák egymás mellé helyezésével tudatossá (és szituációfüggővé) tesszük nyelvhasználatukat.

Például: Melyik nyelvváltozat normájához igazodott a beszélő? Keress megfelelő szituációt az adott megnyilatkozás(ok)nak! Ali követe faintos cuccokkal próbálta a törökökhöz csábitani az apródokat. Vagy: Akarnák inni egy bögre tejet. (Vö. Bartalis et al. 2017.)

Egy másik lehetőség: Melyik megnyilatkozást szoktad használni? Ismered-e/hallottad-e a másikat?. Például: Meg-e találtad már / Megtaláltad-e már?; El kell menjek a boltba. / El kell mennem a boltba. (Vö. Bartalis et al. 2017.)

2.5. A 2.3.-ban megjelenített tankönyvben (Baloghné-Baranyai 2015), kicsivel később mintha fellazulna a preskriptív szemlélet, amikor a tankönyvírók a nákolással kapcsolatban a helyes formáról beszélnek, mert megemlítik, hogy van, ahol más nyelvi forma használata is helyes:

(7) Vannak, akik keverik az általános és a határozott ragozást feltételes módban (meginnák egy kis vizet). Helyesen az általános ragozású egyes szám első személyü alak: meginnék. (Előfordulhat olyan eset, hogy a -nák végződésü, általános ragozású ige is helyes, például a palóc nyelvjárásban.) A meginnák ugyanis a határozott ragozású többes szám harmadik személyü alaknak felel meg (ök is meginnák a vizet). Olyat is hallani, hogy el szokok utazni. Pedig a szokik igének csak múlt idejü alakja van (szoktam, szoktál, szoktak) (Baloghné-Baranyai 2015: 60).

Deskriptív szemléletről azonban nem beszélhetünk, ugyanis ott a szigorú elöírás: a szokik igének csakis múlt idejű alakja van. Érdemes figyelni a mondatkezdésre is: „Olyat 
is hallani [...]" Tehát rácáfol a tankönyv a valós nyelvi praxisra. Felmerül a kérdés, hogy akik ezt a nyelvi formát használják, mind rosszul beszélik a magyar nyelvet?

Üdvözlendők tankönyveinkben az ehhez hasonló deskriptív jellegű megjegyzések, azonban a tankönyvírók nem dolgozták ezt egybe a teljes tankönyvi szöveg szemléletével.

2.6. Vizsgáljunk meg most egy középiskolai tankönyvet!

(8) Az írott köznyelv, a standard társadalmi szempontból a legfontosabb nyelvváltozat, amely a magyarban is a sikeres kommunikáció alapja. (Fráter 2013: 48; kiemelés az eredetiben).

A megállapítás első fele a valós nyelvi praxisnak megfelelö, hiszen a sztenderd tényleg a legnagyobb presztizzsel rendelkezik a társadalomban.

A kijelentés második fele azonban megkérdőjelezhető. Ez ugyanis azt implikálja, hogy más nyelvváltozat használata nem vezet sikerre a kommunikációban, mely nézet egyrészt tudománytalan, másrészt ellentmond a valós nyelvhasználatnak. A szlengben vagy bármely nyelvjárásban beszélő nem tud sikeresen kommunikálni? Vannak olyan helyzetek, amikor éppen szubsztenderd nyelvváltozat vezet sikerre a kommunikációban! Sőt nem is biztos, hogy csak a kommunikációs szempont vezeti a nyelvhasználót. Lehet, hogy elsődleges célja saját identitásának, hovatartozásának vagy éppen elhatárolódásának kifejezése egy adott kommunikációs helyzetben a választott nyelvi forma által.

És hogy mennyire veszélyes ezt éppen a diákoknak kijelenteni, hiszen ez a korosztály azonnal rácáfol erre. Minden pillanatban csetel a közösségi oldalakon, és mennyire sikeres a kommunikációja! És mennyire eltér a köznyelvtől! Mennyire nem szeretné a köznyelvet használni, mert akkor mit is gondolnának róla a többiek? És végül mennyire szeretne (többnyire nem tudatosan) azonosulni azzal a nyelvváltozattal (vagy azokkal a variánsokkal), amelye(ke)t ott használ!

2.7. Ezzel a nézettel azonban nem áll összhangban az a tankönyvi szövegrész, amelyben a szerző kijelenti, hogy a nyelvközösségben több norma létezik, melyekhez egy adott közösségben és környezetben igazodni illik:

(9) Minden nyelvben több nyelvváltozat, $s$ mindegyik nyelvváltozatban több nyelvhasználati mód is van. A beszélők ezek közül válogatnak a mindenkori kommunikációs helyzet függvényében (Fráter 2011: 54).

Felmerül a kérdés, hogy akkor most igazodni kell más normákhoz is, vagy nem szükséges, hiszen ott a sztenderd, amely minden helyzetben a legmegfelelöbb. 
2.8. Egy másik következetlenség ugyanebből a tankönyvből: a 9. évfolyamos leíró grammatikai tananyagrész több nyelvhelyességi megjegyzést tartalmaz, melyek a sztenderd nyelvi normához való alkalmazkodást követelik meg a tanulótól úgy, hogy nincs szó a szubsztenderd formákról, vagy éppen a köznyelv ma már érezhető változásairól. A 12. évfolyamos tankönyvben azonban Nádasdy Búcsú a nyelvhelyességtöl címü írása található, amelyben a nyelvész nyelvészetileg indokolatlannak tartja ennek létét, és a nyelvhelyességet normakövetésként, csoporthoz való tartozásként, azzal való azonosulásként, szerepvállalásként definiálja. A tanulónak véleményt kell alkotnia, illetve válaszolni a szerző felvetéseire.

Helyeselhető, hogy a tantervi elöírásoknak megfelelően a tudatos nyelvhasználatra nevelést valósítja meg a tankönyv, azonban a magyarázat, a döntés segítése a tanárra marad, akit a tankönyv szemlélete nem segít a feladatmegoldásban, hiszen az igencsak ambivalens.

2.9. Egy utolsó példát kívánok még megjeleníteni a következetlenség bemutatásra - szintén egy középiskolai tankönyvünkből.

A kísérleti tankönyvben egyszer egyetlen normáról mint sztenderdröl szólnak a szerzők, más helyeken meg a normapluralizmus nézetét vallják:

(10) A nyelvi norma az ún. igényes köznyelvnek megfelelő szabályrendszer. A nemzeti nyelv normatív változata az ún. sztenderd, amely minden változat felett áll (Balázs et al. 2016: 90).

Másutt ez olvasható:

(11) Nem általában a nyelvnek van normája, nem is csupán az irodalmi nyelvet lehet normának tekinteni, hanem a nyelven belül minden nyelvváltozatnak, sőt beszélőközösségnek megvan a maga normarendszere. Az egyes nyelvváltozatok nyelvi normái közötti viszonyt a tekintély és a megítélés értékei irányítják (Balázs et al. 2016: 53).

Egy lappal később a sztenderd nyelvváltozatot megint azonosítják a normával, de már úgy, hogy - egy újabb fogalmat bevezetve - még a nyelvi eszménnyel is azonossá teszik:

(12) Mivel az irodalmi nyelv meglehetősen félreérthető, újabban inkább nyelvi eszményről, normáról és sztenderdről (régebben: standard) beszélnek (Balázs et al. 2016: 54).

\section{Reflektálás a problémára}

Nyolcosztályos gimnáziumban két évtizede tanító magyartanárként folyamatosan szembesülök az ilyen jellegű, a nyelvi normaszemléletet érintő, valós nyelvi praxist ignoráló 
szövegrészekkel, illetve a gyakorlati tudásanyagban szereplő, hasonló jellegű feladatokkal. Újabban azonban egyre több következetlenséggel is.

Részben a tanórai megfigyelés és tapasztalat, részben (szakdolgozatokban is megtalálható) kisebb-nagyobb mintákon végzett felmérések (többek között: Borbás 2010; Szabó 2008a, 2008b) eredményei is alátámasztják: az a nyelv, amellyel a tanulók a nyelvtanórákon a vizsgálat tárgyaként találkoznak, nemigen hasonlít arra, amely a társadalmi praxisban körülveszi őket.

Anyanyelvi nevelésünk nem számol a tantárgy specifikumával: a tanuló egy vagy több norma birtokosaként kerül az iskolába. Nem befogadóvá, csak egy jórészt életidegen nyelv(használat) elfogadójává válhat. A számára „mintaként”, szabályokként közvetített normák nem internalizálódnak személyiségébe, mely így hosszú távú sikert nem hozhat az anyanyelvi nevelésben. Márpedig az iskola nem mondhat le az anyanyelvoktatás alapvető céljáról és feladatáról, hogy jól, hatékonyan kommunikáló, a különféle stílusokat és regisztereket, kódokat autonóm módon kezelni tudó fiatalokat bocsásson ki falai közül.

\subsection{Egy kutatás bemutatása}

Ez motivált arra, hogy egy kutatást végezzek, amelynek során magyar nyelvi tankönyvek normaszemléletét vizsgáltam: mintegy 200 tankönyvet, a hozzájuk tartozó munkafüzeteket, tanári kézikönyveket, melyeket a magyarországi anyanyelvoktatásban használtak, illetve még használnak (átdolgozott kiadásokat is vizsgáltam) az általános iskolákban, a gimnáziumokban és szakközépiskolákban a 10-18 éves korosztály tanításában. Az anyanyelvoktatás kezdete óta megjelent tanterveket is górcső alá vettem.

Vizsgálati célként a következőket jelöltem meg: (1) A normaértelmezés bemutatása a tananyag elméleti és gyakorlati síkján. (2) A korszak nyelvtudományi gondolkodásmódjának megfelelő normaszemlélettel való összehasonlítása. (3) Ennek összevetése a tantervi normaszemlélettel. Kutatói kérdésem pedig így hangzott: megvalósították-e az egyes korszakok a tanulónak a nyelvi valóságba való integrációját?

\subsubsection{Kutatási eredmények}

3.1.1.1. A tanterveket illetően azt találtam, hogy a rendszerváltás előtt a szocializmusig az irodalmi nyelv mint sztenderd nyelvváltozat a műveltséggel és a kodifikált grammatikához alkalmazkodó helyes beszéddel azonosítódott egy preskriptív szemléletben: a „helyes magyarság” (1932), a „müvelt társalgás nyelve” (1938), az „értelmes, tiszta, helyes beszéd" (1941).

A szocializmus idején a nemzeti eszme kapcsolódott össze a preskriptív norma fogalmával: a "nemzeti nyelv" (1963). A rendszerváltás után a több normához való alkalmazkodás megtanítása a nyelvhelyességi szemlélet megtartásával van jelen a nemzeti alap- és kerettantervekben: az „igényes” magyar nyelv (NAT 1995, 2003, 2007, 2012). 
3.1.1.2. Ami a tankönyveket illeti, a vizsgálat elején megfogalmazott kutatói kérdésre, hogy megvalósították-e az egyes korszakok a tanulónak a nyelvi valóságba való integrációját - néhány taneszköztől eltekintve - nemmel válaszolhatunk a teljes magyarországi anyanyelv-oktatási gyakorlatra nézve. Napjainkban pedig még mindig csak részben valósul ez meg.

Tankönyvíróink a tantervi előírások bázisán, a nyelvtudomány új eredményeinek felhasználásával (ez a mai tanterveket is jellemzi) magas szinten tesznek eleget a kommunikációs helyzetek szerinti nyelvhasználat tanításának.

A normaszemlélet szempontjából változás kezdődött már a 2000-es évek első évtizedében egyes tankönyvekben, amikor a szubsztenderdet a nyelvhasználat felől kezdték értelmezni:

(13) A nyelvjárásoknak a többi nyelvváltozattól való elkülönítéséhez a nyelvi-szerkezeti szempontokon kívül szükség van a beszélőközösség szubjektív véleményére (Balázs-Benkes 2007: 48).

Volt olyan tankönyv, ahol megjelent a normapluralizmus az elméleti ismeretanyag szintjén:

(14) Nemcsak egy, hanem több „norma” is létezik a nyelvben. A köznyelvi norma mellett saját normarendszerük van a nyelvjárásoknak és a szociolektusoknak is (Hajas 1996: 57; 2004: 93).

Sőt elkezdték szétválasztani a(z) (nyelvi) eszmény, norma és a sztenderd fogalmát (Balázs-Benkes 2007: 45) is. Azonban ezek a változások nem váltak általános tendenciává.

Napjaink tankönyvírói nem alkotnak meg egy olyan koherens elméleti koncepciót és ennek alapján kialakított tananyag-elrendezést, amely annak minden részében (a grammatikától a szövegtanon át a stilisztikáig és a nyelvtörténetig) a nyelvhasználatot szolgálná. Úgy gondolom, a következetlenségek is innen származnak: felhasználják ugyanis az új szemléleteket, a nyelvtudomány új eredményeit, azonban nem megfelelő módon (sokszor következetlenül) integrálják ezeket a tananyagba.

A normát szigorú szabályrendszerként értelmezve, azt közvetítik a tanuló felé, hogy a beszélőközösségei által rákényszerített mintát kell követnie beszédhelyzettől függően. Elhallgatják előle azt a lehetőségét, hogy ő maga is alakít(hat) ezen a mintán interakciói során - éppen a közösségétől ráhagyományozott, gyakorlati jellegű tudása alapján. Ezzel értené meg a tanuló az őt körülvevő nyelvi valóság általa naponta megtapasztalt heterogenitását, valamint egyénre és közösségre szabott flexibilitását. Ezzel tudnák a tankönyvek integrálni őt a nyelvközösség élő nyelvhasználatába.

Az élő nyelvhasználat tanításának megvalósítására, illetve a tanulónak a nyelvközösség sokszínű és sokrétű nyelvhasználatába való integrációjára mégis találtam példákat 
a magyarországi nyelvtankönyv-írásban. A 19. és 20. század fordulóján Simonyi, majd egy évszázaddal később Bánréti Zoltán és a Kugler - Lengyel - Tolcsvai Nagymunkacsoport tankönyvei, amelyek preskripciótól mentes nyelvhelyességi szemlélettel, a nyelvszokás állandó ellenőrzése mellett (vö. Tolcsvai Nagy 2004: 54), a sztenderd norma nyelvközösségben kiemelt szerepének szem előtt tartásával is képesek voltak normakövető és normaalkotó egyének nevelésének megvalósitására.

Példaként tekintem mindenekelőtt Simonyi deskriptív jellegű, szociokulturális alapú, rugalmas normaszemléletét (Simonyi 1889). Simonyi és Bánréti sztenderdfelfogását, miszerint a sztenderd „a köznyelv vagyis közös nyelv” (Simonyi 1905: 37), amely „nem jobb, mint bármelyik dialektus vagy szociolektus. Az a funkciója, hogy közvetít a nyelvváltozatok között" (Bánréti é. n.: 142).

Az említett munkacsoport nyelvváltozat-meghatározását is példának tekintem. Ők a beszélőik felől közelítik meg az egyes normákat:

(15) A nyelvváltozat nem egyszerủen a hangtani, szókészleti, nyelvtani vagy jelentéstani különbségek által jön létre, hanem azáltal, hogy ezek a különbségek viszonylag következetesen kapcsolódnak valamilyen földrajzi vagy társadalmi réteg, csoport (vagy mindkettő) nyelvhasználatához, ill. valamilyen beszédhelyzethez (Kugler - Tolcsvai Nagy 1998: 148).

A beszélő döntése az egyetlen mérvadó abban, hogy az általa beszélt nyelvi variánst elkülöníti-e a többitől, illetve ugyanazon nyelv részének tekinti-e (Sándor 1999: 162).

\section{Javaslataim}

Szükséges megjeleníteni a kommunikációs funkciók mellett az egyéni és közösségi identitásjelzést is a tankönyvek általános nyelvészeti fejezeteiben vagy a nyelv és társadalom témakörén belül.

Azt is hangsúlyossá kellene tenni, hogy az adott nyelvközösségben működő több norma léte azok beszélöi felöl értelmezendő.

Nyelvhasználati (pragmatikai) tényezők bevonására lenne szükség ahhoz, hogy a nyelvi formák funkcióit láttatni tudjuk. A jelentés elsődlegessége és a hozzá rendelhető nyelvi kifejezésmódok bemutatása több norma együttes jelenlétére utal az oktatás során. Ugyanakkor azt az információt is hordozza, hogy nem a grammatikai szabályok irányítják a nyelvhasználatot, hanem a beszélőközösség nyelvszokása az elsődleges, amely magát a szabályt is életre hívta és szüntelen alakítja (vö. Brassai 1895).

A szituációfüggő tanítási-tanulási folyamatban számolni kellene a tanulók normaalkotó képességével is; meg kellene mutatni, hogyan, miként lehetséges eltérni az egyes normáktól, milyen következményekkel járhat ez (vö. Bánréti 1990: 21). 
Az élő nyelv tanítását technikai lehetőségeink alkalmazásával javaslom megvalósítani. A 21. századi anyanyelvoktatás egyik hiányosságának tekintem, hogy a mai technika magas fokán már elvárható követelmény lenne a nyelvi valóság hủ tükreként felfogható hangfelvételek használata az anyanyelvi órán.

Végül tudományos-szakmai összefogás megteremtését, szakmai viták megrendezését, majd a fenti szemlélet alapján, a kárpátaljai anyanyelvoktatásban alkalmazott tantárgy-pedagógiához (Beregszászi 2012) hasonló szemléletű, a nyelvi heterogenitást és flexibilitást funkcionális keretben közvetítő tantárgy-pedagógia kidolgozását javaslom.

Alapvető társadalmi szükséglet ugyanis, hogy anyanyelvoktatásunk megfeleljen korszakunk, a 21. század kommunikációs és nyelvhasználatbeli kihívásainak.

\section{Források}

Antalné Szabó Ágnes - Raátz Judit 2001. Magyar nyelv és kommunikáció. Tankönyv a 9-10. évfolyam számára. Budapest: Nemzeti Tankönyvkiadó.

Antalné Szabó Ágnes - Raátz Judit 2007. Magyar nyelv és kommunikáció. Tankönyv a 9-10. évfolyam számára. Budapest: Nemzeti Tankönyvkiadó.

Balázs Géza - Benkes Zsuzsa 2007. Magyar nyelv a gimnáziumok és a szakközépiskolák 10. évfolyam számára. Budapest: Tankönyvkiadó.

Balázs Géza - dr. Forró Orsolya - dr. Hegedűs Attila, Szoták Szilvia 2016. Magyar nyelv. Budapest: OFI.

Baloghné Bíró Mária - dr. Baranyai Katalin 2015. Magyar nyelv és kommunikáció 6 . Budapest: OFI.

Bánréti Zoltán 1990. Nyelvtan-Kommunikáció-Irodalom tizenéveseknek. Programleirás. Budapest: MTA Nyelvtudományi Intézete.

Bánréti Zoltán é. n. Nyelvtan és kommunikáció II. (Szövegtan, nyelvelmélet, generativ mondattan) 7-9. osztály. Veszprém: Nodus Kiadó.

Bartalis Boróka - Köllő Zsófia - Orbán Zsuzsa-Lilla - Szőcs Hedviga - Tamás Adél 2017. Magyar nyelv és irodalom (anyanyelv) V. osztály. Marosvásárhely: Kreatív Könyvkiadó.

Beregszászi Anikó 2012. A lehetetlent lehetni. Tantárgy-pedagógiai útmutató és feladatgyüjtemény az anyanyelv oktatásához a kárpátaljai magyar iskolák 5-9. osztályában. Budapest: Tinta Könyvkiadó.

Fráter Adrienne 2011. Magyar nyelv a középiskolák számára. 10. Szeged: Mozaik Kiadó. Fráter Adrienne 2013. Magyar nyelv a középiskolák számára. 12. Szeged: Mozaik Kiadó. Hajas Zsuzsa 1996. Magyar nyelv IV. Debrecen: Pedellus Tankönyvkiadó. Hajas Zsuzsa 2004. Magyar nyelv 12. Debrecen: Pedellus Tankönyvkiadó. Kugler Nóra - Tolcsvai Nagy Gábor 1998. Magyar nyelv. Tankönyv 14-15 éveseknek. Budapest: Korona Kiadó.

Lerchné dr. Egri Zsuzsa 2001. Anyanyelv felsösöknek. Tankönyv 5. Szeged: Mozaik Kiadó. 
Lerchné dr. Egri Zsuzsa 2016. Anyanyelv felsösöknek. Tankönyv 6. Szeged: Mozaik Kiadó. Lerchné dr. Egri Zsuzsa 2017. Anyanyelv felsösöknek. Munkafüzet 6. Szeged: Mozaik Kiadó. Simonyi Zsigmond 1889. Magyar nyelv II. Budapest: MTA.

Simonyi Zsigmond 1905. Magyar nyelvészet középiskolák legfelsö osztályainak és a tanitóképzö intézeteknek. Budapest: Athenaeum.

\section{Irodalom}

Borbás Gabriella Dóra 2010. Konceptuális váltás szükségszerủsége a nyelvhasználat kontrolljáról való gondolkodásban (A közoktatás felelössége). Alkalmazott Nyelvészeti Közlemények 5/2: 51-63.

Brassai Sámuel 1895. Qui bene distinguit, bene docet. Fövárosi Lapok. 1895. március 18.

NAT 1995 = Nemzeti alaptanterv. Művelődési és Közoktatási Minisztérium - Korona Kiadó.

NAT $2003=243 / 2003$. (XII. 17.) Korm. rendelet a Nemzeti alaptanterv kiadásáról, bevezetéséről és alkalmazásáról. http://www.nefmi.gov.hu/letolt/kozokt/nat_070926. pdf (2019. 04. 29.)

NAT 2007 = Nemzeti alaptanterv 2007. http://www.zipernowsky.hu/letoltes/kerettanterv/nat_070815.pdf (2019.04. 29.)

NAT $2012=$ 110/2012. (VI. 4.) Korm. rendelet a Nemzeti alaptanterv kiadásáról, bevezetéséről és alkalmazásáról. Magyar Közlöny 66: 10635-10848. http://ofi.hu/sites/ default/files/attachments/mk_nat_20121.pdf (2019. 04. 29.)

Sándor Klára 1999. Szociolingvisztikai alapismeretek. In: Galgóczy László (szerk.): Nyelvtan, nyelvhasználat, kommunikáció. Szeged: JGYF Kiadó. 134-171.

Szabó Tamás Péter 2008a. „Idegesít, mert borzalmasan hangzik.” Gimnazisták a nem önvezérelt nyelvi hibajavításról. In: Gherdán Tamás - Schultz Judit (szerk.): Félúton 2. Az ELTE BTK Nyelvtudományi Doktori Iskolájának konferenciája. 2006. június 13-14. Budapest: ELTE BTK Nyelvtudományi Doktori Iskola. 100-109.

Szabó Tamás Péter 2008b. A nyelvhelyességi szabályokkal kapcsolatos metanyelvi tudás formálása. In: Váradi Tamás (szerk.): II. Alkalmazott Nyelvészeti Doktorandusz Konferencia. Budapest: MTA Nyelvtudományi Intézet. 87-98.

Tolcsvai Nagy Gábor 2004. Alkotás és befogadás a magyar nyelv 18. század utáni történetében. Budapest: Áron Kiadó. 